DOI: $10.17516 / 1997-1370-0736$

УДК 398.22(=512.157); 398.22(=512.156)

\title{
On the Functional Features of Image-Forming Verbs in Yakut and Tyvan Epic Texts: Comparative Analysis
}

\author{
Liliya N. Gerasimova* \\ M.K. Ammosov North-Eastern Federal University \\ Yakutsk, Russian Federation
}

Received 31.08.2020, received in revised form 02.02.2021, accepted 06.04.2021

\begin{abstract}
This work examines the image-forming verbs of the Yakut and Tyvan languages, selected from the Yakut olonkho Dyyray Bogatyr, The Son of the Horse by I.I. Burnashev and the Tyvan heroic epic Khunan Khara by Chanchy-Hoo Oorzhak in order to identify semantic equivalents and functional features of verbs in epic texts, which will contribute to the definition of genetic communities and differences between the Turkic languages and the epic tradition. In analyzing of material, the method of continuous sampling, component analysis method, method of context (distributive) analysis and comparative method were used. The Yakut storyteller pays more attention to detailed and figurative descriptions to create entertainment, colorful pictures and actions, and the Tyvan storyteller - to movements, the course of actions for liveliness and brightness of the course of events, the development of plots. Yakut verbs are used in their original forms and in the forms formed using affixes of specific forms. And Tyvan verbs are used in forms based on the affixes of word formation of verbs and auxiliary verbs. The result of the study allows us to conclude that the functional feature and commonality of the Yakut and Tyvan image-forming verbs lie in their direct participation in the creation of images, description of pictures, and characterization of actions and transmission of feelings.
\end{abstract}

Keywords: image-forming verbs, Turkic epics, functional feature, olonkho, Tyvan epic.

The study was carried out as part of the NEFU research project «Epic monument of the Yakut intangible culture: textological, typological, cognitive and historical-comparative aspects».

Research area: philology.

Citation: Gerasimova, L.N. (2021). On the functional features of image-forming verbs in Yakut and Tyvan epic texts: comparative analysis. J. Sib. Fed. Univ. Humanit. Soc. Sci., 14(4), 489-503. DOI: $10.17516 / 1997-1370-0736$.

(C) Siberian Federal University. All rights reserved

* Corresponding author E-mail address: gelinica@yandex.ru ORCID: 0000-0002-9594-7824 


\title{
О функциональных особенностях образных глаголов в якутском и тувинском эпических текстах: сравнительный анализ
}

\author{
Л.Н. Герасимова \\ Северо-Восточный федеральньй университет \\ им. М.К. Амиосова \\ Российская Федерачия, Якутск
}

\begin{abstract}
Аннотация. В данной работе рассмотрены образные глаголы якутского и тувинского языков, отобранные с героических эпосов якутского олонхо «Сын лошади Богатырь Дыырай» Бурнашева И.И.-Тонг Суорун и тувинского героического сказания «Хунан Хара» Чанчы-Хоо Ооржака с целью выявления семантических эквивалентов и особенностей функционирования глаголов в эпических текстах, что внесет свою лепту в определении генетических общностей и различий тюркских языков и эпической традиции. Распределение глаголов по семантическим значениям сделано по классификации Л.Н. Харитонова. Якутский сказитель больше внимания уделяет детальному и образному описанию для создания зрелищности, красочности картин и действий, а тувинский сказитель - движениям, ходу действий для живости и яркости течения событий, развития сюжетов. Результат исследования дает нам возможность сделать вывод о том, что функциональная особенность и общность якутских и тувинских образных глаголов заключается в их непосредственном участии в создании образов, описании картин, характеристике действий и передаче чувств.
\end{abstract}

Ключевые слова: тюркские языки, образные глаголы, олонхо, тувинский эпос, функциональная особенность, эпическая традиция.

Исследование выполнено в рамках научно-исследовательского проекта СВФУ «Эпический памятник нематериальной культуры якутов: текстологический, типологический, когнитивный и историко-сравнительные аспекты».

Научная специальность: 10.00 .00 - филологические науки.

\section{Introduction}

B.N. Putilov and his statement that "the epic text language research is the most genuine path to reaching an in-depth understanding of the monuments of epic culture" (Putilov, 1978: 8); E.I. Ubriatova states that "the uniqueness of the Yakut language has always required its comparison with other similar Turkic language materials in every detail" (Ubriatova, 1960: 1); these statements justify the reasoning for a comparative analysis of the similar Turkic language epics, in our case, it's the Yakut and Tyvan languages.

A comparative study of the Yakut heroic epic and other Turkic-Mongolic epic was first conducted by I.V. Pukhov (2003), who indicated the general, similar, and various features in the plot, images and styles of the epics. In recent years, the following scholars have conducted research on the Yakut and Tyvan epics - V.V. Oboiukova (Oboiukova, 2015), M.T. Gogoleva (Gogoleva, 2015), A.F. Koryakina (Koryakina, 2020); these scholars have singled out the typological and genetical links in terms of the plot and compositions structure, the motifs, and the incorporation of the expressive means and stylistics devices along with the artistic details in the epic plots under study.

The storyteller, who creates and unravels the text of the epic story-line, focuses largely 
on the word and phrase choice in the plot as well as how the melody and tune is produced while telling the story; i.e., it is as if the storyteller intentionally focuses our attention to the language form of expression, adapting the listener to a conscious and active perception of the plot (Hertek, 2015: 188). In order to fully and vividly project the image, the expressions of feelings and emotions, the storytellers often incorporate descriptive vocabulary, including the abstract and image-imitating verbs.

The presented research overviews the image-forming verbs of the Yakut and Tyvan languages, which were selected from the texts of the heroic epics. The Yakut olonkho written by I.I. Burnashev Dyyray Bogatyr, The Son of the Horse (6687 lines) (Burnashev, 2013) and the Tyvan heroic epic by Chanchy-Hoo Oorzhak Khunan Khara (5442 lines) (THL, 1997).

The Tyvan language is a language of the Turkic group of language of the Sayan-Altai region. The Yakut language is frequently associated with the same group and region of languages. N.A. Baskakov classifies this the Tyvan language under the Uyghur-Tukyuk subgroup of the Uyghur-Oguz group, while the Yakut language belongs to the the Yakut subgroup of the Uyghur-Oguz group (Baskakov, 1969: 313-349). V.I. Rassadin notes that "it would have been a productive thorough and in-depth research if the inner group of the Sayan-Altai Turkic languages areal was studied; the research would help to get a bigger and clearer picture on the features, which these language groups have in common and, therefore, they could possibly belong to the ancient Turkic language, which spread among the aboriginal population of the region under study" (Rassadin, 1981: 231).

Thus, the relevance of this research is based on the insignificant amount of existing research on the incorporation of the image-forming vocabulary in the epic texts as well as the necessity to overview and analyze the use of the image-forming verbs of the Yakut language compared to the Tyvan image-forming verbs with the aim of distinguishing the semantic equivalents and special features governing the functioning of these verbs in the epic texts; this would contribute to defining the common and differentiating genetic features of the Turkic languages and the epic story-telling tradition.

The descriptive and image-forming verbs present a special lexical and semantic group of verbs, the meaning of which conveys "the emotional perception and movement and these play the key role; meanwhile, the visual images are incorporated most frequently" (Kharitonov, 1960: 203). Monographs written by L.N. Kharitonov $(1947 ; 1954 ; 1960)$ are the original sources devoted to the study of the Yakut language image-forming verbs. It is worth mentioning that in the previous years, the Yakut linguistics have studied separate groups of image-forming verbs; thus, N.N. Efremov (Efremov, 2017) studied the verbs of movement; E.E. Zhirkova (Zhirkova, 2017) overviewed the verbs depicting the human manner of walking. A range of articles was published on the comparative and contrastive study of the image-forming verbs of the Mongol (Monastyrev, Efremov, 2019; Shamaeva, Prokop'eva, 2019) and Kyrgyz languages (Argunova, Sorova, 2019).

In the "Grammar of the Tyvan language. Phonetics and morphology", the image-forming words, perceived as being a part of imitative vocabulary, are included into the group of interjections; word-formation of the image-imitative verbs is included in the section devoted to the verbs word-formation (Iskhakov, Palmbakh, 1961: 256-274, 459-461). The phonetic and structural features of the imitative words of the Tyvan language have been studied by C.M. Dorzhu (Dorzhu, 1980), while N.C. Sereedar (Sereedar, 2011) analyzed the onomatopoetic verbs in basic simple sentences with a sound-forming meaning. N.M. Ondar (Ondar, 2004) carried out an analysis of the repetitive structures' features conveyed in the sound- and image-imitating words. Therefore, presently there has not been a special study conducted devoted to the lexical and grammatical group of image-forming verbs in the Tyvan language. For this reason, the main source in classifying the verbs of the Yakut and Tyvan lanaguages is the monograph by L.N. Kharitonov titled Types of verbal stems in the Yakut language (Kharitonov, 1954), in which the scholar outlines the general theoretical statements in the respect to the image-forming verbs as such being a sepa- 
rate type of verbal stems of the Yakut language; the author of the monograph also provides a semantic classification, and, in addition, the typological forms as well as the phonetic features of the image-forming verbs.

In the course of analysis, the continuous sample method was used in selecting the verbs from the epic texts; the component analysis method, which overviews the meaning of the word as such consisting of elementary meanings (features, components, and semes); the method of contextual (distributive) analysis, which allows singling out various meanings and shades of meanings of the verbs under study in terms of their functions performed in the text; the comparative method which was used in comparing the Yakut verbs to the Tyvan verbs.

\section{Classification of Image-Forming Verbs}

The Yakut olonkho text revealed $84 \mathrm{im}-$ age-forming verbs, while the Tyvan epic tales revealed 13 of such verbs. The verbs were classified in terms of their semantic meaning using the classification proposed by L.N. Kharitonov: the verbs of motion and visual image; verbs of sense perception were not detected in the analyzed texts as "they did not receive any morphological development in the Yakut language" (Kharitonov, 1954: 212):

Verbs of movement in the Yakut language:

- verbs expressing movement in a general meaning (total 16):

a. dzhigihiy 'to come into a rocking movement, to shiver, to shutter' (BEDYL, V. 3: 333);

b. unaariy 'to lay flat, to stretch out; to move, or to act too slowly' (Kharitonov,1954: 300);

- verbs characterizing human manner of walking, movement of the body and parts of the body (total 13):

a. maadzay 'to obtain a bent leg' (BEDYL, V. 6: 176);

b. maray 'stick out one's chest when walking or running' (BEDYL, V. 6: 231);

- verbs expressing movement associated with the external shape and structure of an object or body (total 5): a. hodzhoy '1. to move with a jump; walk with a bouncing gait, being tall and slender; 2 . to move, run with a jump, stretching in length' (BEDYL, V. 13: 503);

b. kuybangnaa 'wriggle, wag, smoothly bend' (BEDYL, V.4: 440).

Verbs expressing visual images in the Yakut language:

- verbs characterizing the appearance, form and structure of the object (total 24):

a. dallai '1. spread arms or wings sideways; 2 . to be excessively large, wide, protruding; 3. become visible, gradually expanding, increasing in volume' (BEDYL, V. 3: 101);

b. kultey 'to be swollen, inflated; stand out pout, increased in volume in a rounded shape; be convex, bulging' (BEDYL, V. 4: 609);

- verbs characterizing the physique and figure of a person (total 14):

a. darai 'have, broad shoulders; seem broad shouldered' (BEDYL, V. 3: 108);

b. motoy 'stick out one's chest' (BEDYL, V. 6: 326).

- verbs characterizing facial expressions and a person's face (total 2):

a. appangnaa 'from verb appai: 1 . to open slightly, not close completely; 2 . carelessly wide-open mouth' (BEDYL, V. 1: 505);

b. nielbey 'to have a swollen, inflated appearance as a consequence of stress' (BEDYL, V. 7: 182).

- verbs characterizing light perception (total 11):

a. kundeier 'shine dazzlingly, shine with a bright light' (Kharitonov, 1954: 290);

b. tunaliy 'be, seem dazzling white, stand out in bright white color' (BEDYL, V. 9: 115).

Verbs of movement in the Tyvan language:

- verbs expressing movement in a general sense (total 2):

a. elengne '1. walk (go) staggering; 2. swing, sway' (TRD, 1968: 612);

b. tendingeier 'stagger, swing (in case of loss of balance)' (TRD, 1968: 410); 
- verbs characterizing the manner of walking, movement of the body and body parts (total 3):

a. chivesh daa 'blink; glisten, flicker' (TRD, 1968: 531);

b. davy 'bounce with joy' (TRD, 1968: 140);

- verbs expressing movement associated with the external form and structure of an object or body (total 2):

a. kiybyngna 'to fidget, spin; move' (TRD, 1968: 275);

b. saglangaiyin 'to move, sway, tremble' (TRD, 1968: 360).

Verbs of the visual image in the Tyvan language:

- verbs characterizing the appearance, form and structure of the object (total 1):

khalangna 'hang out (about smth.)' (TRD, 1968: 464);

- verbs characterizing facial expressions and a person's face (total 2):

a. dyrysh '1. to frown; 2. to scorch' (TRD, 1968: 195);

b. kylchangna 'to look from underneath (viciously)' (TRD, 1968: 276); (total 2):

- verbs that characterize light perception

a. chyrytkyla 'shine, glimmer, flicker' (TRD, 1968: 559);

b. herelden 'to radiate, to give off light, emit rays; to spread (rays)' (TRD, 1968: 276).

\section{Structure of Image-Forming Verbs Stems}

The Yakut language image-forming verbs structure indicated in the olonkho, contains verbs which are used in both - the original and the transformed form (total of 8 verbs):

a. arbay 'to gradually and widely spread oneself, or to tremble' (Kharitonov, 1954: 285) - arbay, arbangnaa;

b. kylay 'to shine giving off a bright spot of light at a far distance or to shine through smth, to glisten, to barely be seen, to be seen faintly (used when talking about small objects)' (BEDYL, V. 5: 215) - kylay, kylalyn; c. kylbay '1. to shine brightly; be or seem to be bright or shiny, to glimmer; 2 . to shine with a white light, to whiten, 3. to be or appear to be bright or light-colored; to shine with novelty or freshness' (BEDYL, V. 5: 225) - kylbay, kylbahiy;

d. kyntay 'to be slim, with one's head held high, proudly' (BEDYL, V. 5: 272);

e. suoday 'be, or appear to be giant-sized, large, be of a considerable height' (BEDYL, V. 9: 134) - suoday, suodaghys gyn;

f. tomtoy 'be or appear to be distinct, rounded, to stand out' (BEDYL, V. 10: 444) tomtoy, tomtoldzhuy;

g. unaariy 'to lay flat, to stretch out; to move, or to act too slowly' (Kharitonov, 1954: 300);

h. chikkey ' 1 . to be tightly strained, not to dangle; 2. to straighten up, to stretch out like a stick, to stand up and straighten up quickly' (BEDYL, V. 14: 132) - chikkey, chikkeldzhiy, chikkes gyn.

Examples of transformed forms include the following verbs:

- in the form of a split multiplicity of an action using the -ldzhiy affix [total of 9 verbs]:

a. laglay 'to have a low-positioned, wide, and spreading crown; to be short, stout, and equally wide (when referring to the form of smth, someone's complexion)' (BEDYL, V. 6: 72) - laglaldzhiy;

b. halbay 'to fall off the track, to lose one's initial place, to decline (from smth)' (Kharitonov, 1954: 301) - halbaldzhiy;

- in the form of unfolded multiplicity of an action using the -ngnaa affix (total of 4 verbs):

a. appai '1. to open slightly, not close completely; 2. carelessly wide-open mouth' (BEDYL, V. 1: 505) - appangnaa;

b. horoy ' 1 . to be or to seem sticking out; 2. colloquial form of: to become taller, to grow' (BEDYL, V. 13: 602) - horongnoo;

- in the form of a shifting multiplicity using the following affixes: -liy, -hiy, -riy (total of 6 verbs):

a. duoday 'to be or to seem excessively tall, lean (when referring to a person, or an an- 
imal with long and thin legs)' (BEDYL, V. 3: 188) - duodaliy;

b. kylbay '1. to shine brightly; be or seem to be bright or shiny, to glimmer; 2 . to shine with a white light, to whiten, 3. to be or appear to be bright or light-colored; to shine with novelty or freshness' (BEDYL, V. 5: 225) - kylbahiy;

c. nyokoy 'to duck down, to bend, to lean forward' (BEDYL, V. 7: 136) - nyokoryus;

- in the form of immediate action using the $-s$ affix:

a. toytoy ' 1 . to be or to seem very small and plump (referring to a person's complexion); 2. to be or to seem very short and stumpy' (BEDYL, V. 10: 424);

b. kyntay 'to be slim, with one's head held high, proudly' (BEDYL, V. 5: 272).

In separate cases, the variation of the vowel and consonant sounds in the stems of the Yakut verbs is quite evident, while the lexical meaning remains the same, for example, myoskoy-byeskey, chomchorus gyn - chyomchorus gyn, achchai-ahchai.

Among the image-forming verbs selected from the Tyvan legends, there are verbs which are formed using the affixes of the word-forming verbs -ngayiyn / - ngeyin: saglay - saglangayiyn; as well as from affixes -ngna / -ngne: doytuy - doytungna, halay - halangna. In addition, verbs formed with the help of the affix $-s h$ and the auxiliary verb $d i-/ d e-$ are used: chyrytkyla - chyrytkylash de-.

The Tyvan image-imitating verbs can be used solely, doubled or in pairs (Iskhakov, Pal'mbakh, 1961: 460). Among the verbs which were included in the analysis, there are several examples of double and paired use. For example, the verb kyybyngna is paired with the verb imilee 'to swarm' (TRD, 1968: 206):

'Хаан кижиниң ара-албатызы / Кара богбаны / Мойнунга уш ораай каккаш, / Өлүг доңнук-биле доңнап-баглап каан, / Адырар дээи, / Чежип чадап каан, / Имилээн-кыймыңнаан турар бооп-тур эвеспе аан (THL, 1997: 166).

«The Khan's servants, / To let the iron horse graze, / Clutching and pushing, it turns out, / They tried to untie it / [The reason] why the black shear, / Three times around the neck [iron horse] was wrapped / And tied with a dead knot» (THL, 1997: 167).

The verbs doytuy and dyrysh are used twice:

Куу бутту куду / Куу даянугыьыш даянып алгаштыц, / Куу даштыг / Кыр тон кедип алгапггың, / Куу шоодай / Чүктеп алгаштың,, / Дойтуңайнып-дойтуңяайнып кылаштап, / Кире-ле бергей мен / Хаанның өөндүве / Дырыжаш-дырыжаш, / Чолдашталдаш кире-ле дүже бергей мен (THL, 1997: 74).

«Dressed in an old-fashioned manner/ With a gray top, / With a thrown behind the back / Gray bag, / Leaning on a gray stick / And limping slightly, / I'm down the gray spur descending [going down], / I will come to them [into the aal] / Angry and furious/ Trembling and shaking, / I will enter the Khan's yurt» (THL, 1997: 75).

The verb elengnye is used once and in terms of paired use, there are examples with the verb tendingeier:

Көвей амытан көруп турда, / У c далайның кылдыьында, / Узун-Сарыг хаан катылмның аальига / Эленнедиптендиңнедип / Чеде берген уеңде барып, / Изиг өкпенни / Өрттендир-хуюкталдыр / Хаарып, быжырып тургаиггың, / Өлүрер мен...' (THL, 1997: 134).

«Arzylan-Kara / Turned / Into a lousy black shear, / Who is about to die. / Having become miserable, insignificant, / [Hunan-Kara] rode / With a small bowl, / Swinging-swaying / In stirrups made of wood / On a badger made of badger skin» (THL, 1997: 135).

and the verb khalangna:

'Халаңнады-элеңнеди / Көруп чортупдаа олурган иргин ийин' (THL, 1997: 260).

«Swinging, swaying, / Riding, watching [Hunan-Kara] makes his way» (THL, 1997: 261).

Due to the lexical and semantic analysis of image-forming verbs, the exact equivalent 
in terms of the stem structure and semantics among the revealed image-forming verbs was found only in the Yakut language verbs kuibangnaa 'wriggle, wag, smoothly bend' (BEDYL, V. 4: 440) and the Tyvan verb kiybyngna 'to fidget, spin; move' (TRD, 1968: 275).

\section{Functions of Image-Forming Verbs in Epic Texts}

1. Image-Forming Verbs in Olonkho

In the course it was revealed that the image-forming verbs of the Yakut language in the epic text are involved in the description of nature. In most cases, image-forming verbs are incorporated when expressing ideas about the nature of the Middle World; they are often given in the introductory part of the epic text, where an initial depiction of life on Earth is presented. For example, the verb meteldzhiy 'bend forward, exposing the stomach' (Kharitonov, 1954: 293) participates in the description of pines:

'Мэссээн нууча кыргыттара / Биэлэй күөх солкоттон тутуһан / Биэрэк сиргэ киирэннэр үнкүүлээн / Мэтэлдьиһэн эрэллэрин курдук / Бэрдьигэс мастаах эбит ээ (Burnashev, 2013: 16).

«Just like smart / Russian girls, gathered / On the shore, holding on / For white and blue shawls, / Moving their hips side to side, / Having a round dance, / Grow magnificent pines».

The verb laglaldzhiy 'from verb laglay: to have a low-positioned, wide, and spreading crown; to be short, stout, and equally wide (when referring to the form of smth, someone's complexion)' (BEDYL, V. 6: 72) is mentioned in an example that colorfully depicts a picture of a birch grove:

Бу ойур унуоргу өттө - / Ханалас улууһун дьахталлара / Дьааһьютаах хампа солколорун /Хаалларбакка таннан, /Урууга, blhblaхха бардыбыт диэн / Бааралаан хаамсан, Лагладьдьыһ ин иһэллэрин курдук / Арысынан алла турар / Apыbl чаллах чараннардаах эбит' (Burnashev, 2013: 18).

«Behind this dense forest - / Not Kangalass women / Did leave in crates / Treasured silk outfits, / Dressed up for Ysyakh, / For a rich wedding, / Go slowly, flaunting - / That's filled with the oily smell and grace / The birch grove smells so sweetly».

During the struggle of the warriors with the help of image-forming verbs the changes taking place in nature are depicted, especially in the seas and rivers, which create a feeling of excitement, experience and transmit the power of the struggle. For example, in the extract with the verb dolguldzuy ' 1 . slightly worry, ruffle; 2. slightly, measuredly flutter; 3 . jolt, jerk to swing, stagger, shake; 4. smoothly walk, move, swim; 5. smoothly transition from one state to another; move smoothly' (BEDYL, V. 3: 154):

'Таас Таалыйа хонууну наймылдыытттылар, / Кыльыл кыппьіайка быһьыттан түстэ. / Улуу муора уута долгулдьуйа турда, / Далай муора уута дьалкыйан та5ыста' (Burnashev, 2013: 128).

«Rocky field of Taalyiya / Was plowed with heavy legs, / Red sands spread; / The great sea was excited, / Deep ocean water / Rises above the coast».

- the size and crushing nature of the battle can be felt.

Special focus is given to the creation of an image of the sacred tree Aal Luuk Mas, as part of nature. The beauty and greatness of the Aal Luuk Mas also affects the beginning of olonkho. The author uses various methods of transmitting the expressivity and imagery, including image-forming verbs. In the example:

'Тойон киһи кымыс иһэр / Оhуор ойуулаах, / Бочугурас ойоқостоох, / ТомторБолоох айахтаах / Чороон ымыйаларын / Таннарыта туппут курдук / Лоһуор көмүс туораахтаах эбит. / Бу аБыс салаата / А5ыс ааттаах урэх баһыгар тиийэннэр / Таннарыта намылысыан түспуттэр эбит' (Burnashev, 2013: 20).

"As if hung overturned, / Festive chorons, / With carved edges, / With patterned sides, / Out of which koumyss is drunk / Famous gentlemen, / With large acorns. / These eight branches, / Having reached the distant sources / of the Eight Great Rivers, / Bent down»,

the verb namyliy 'mix, go down, creep' (Kharitonov, 1954: 293) conveys the meaning 
that the branches of the sacred tree have grown so much that they have become heavy and long, but at the same time the tree retains its sophistication.

Incorporating image-forming verbs also extends itself to the descriptions of natural phenomena and the seasons: the verb unaarys gyn 'from verb unaariy: to lay flat, to stretch out; to move, or to act too slowly' (Kharitonov, 1954: 300) helps to reveal the emergence of smoke from a cloud:

‘Бу турдаБына бу былыт / Оттотунан дьөлө ысстанан хаалла, / Төбөтннэн хайьь баран хаалла. / Халлаан түөт өттүн диэкки / Түөт хамса буруота буолан / Унаарыс гына түспутэ' (Burnashev, 2013: 41).

«A black cloud / Splits in the middle / Into four horizons, / Like from a clay pipe, / From a cloud pulled / Fast smoke».

The verb sandaarys gyn 'emit, radiate, spread bright light; stand out in explicit bright color' (BEDYL, V. 8: 226) is present in the passage where lightning appears and its emergence is being described:

'Халлаан альнн уорБатын диэкиттэн / СУрдээх сүҮнэ улахан / Сааллар чаБыльан уота / Таннары сандаарыс гына түстэ' (Burnashev, 2013: 75).

«Along the edges of the sky / Lightning has struck».

In addition, image-forming verbs are involved in the description of the characters and their actions. Thus, the verbs uokey 'to be slim and slender' (BEDYL, V. 12: 469); biekey 'to be very thin at the waist, slim' (BEDYL, V. 2: 348) and daray 'have, broad shoulders; seem to be broad-shouldered' (BEDYL, V. 3: 108) are used to create a portrait of the main olonkho character - the aiyy bogatyr Dyyray, the Son of the Horse:

Баар эбит, добоор, / Үрдугэ ус бэчээтинэй үтүө киһи, / Алььн тилэБэ былыйга быһыыblлаах, / Оттоку унуоьа бодьуйга боруобалаах, / Үрүт унуоБа модьуга мөссүөннээх, / Үс түһэ кэбиһэ былас / Үнкэйэр өттүктээх эбит, / Биэс былас биэкэйэр бииллээх, / Алта былас дарайар сарыннаах, / Суллаабыт тиит курдук сотолоох, / Уолах мас курдук уллуктаах, / Хастаабыт мас курдук харылаах, / Бысталаабыт тиит курдук былчыннаах, / Сыарқалаах от курдук / Сырыьылаах сырайдаaх’ (Burnashev, 2013: 32).

«It turns out there are friends: / Above are three printed / Good fellow, / Judge by the heels - / The runner is excellent, / Middle bones are thick, / See, strong man, / On three swing fathoms / High hips, / On five swing fathoms / Thin waist, / On six swing fathoms / Broad shoulders turned around, / Shins are like bare stumps/ a strong larch, / Wrist bones are like decks, / It's like a chopped-off trunk / Mighty tree - muscles, / As if they put ten skins / Fire-foxes, cheeks burn».

The verb kilbey 'to illuminate, shine; radiate, sparkle' (BEDYL, V. 4: 93) is used to create a vivid image of the aiyy hero Toyon Joburuontai:

'Киис тириитэ килбэйэр / Дайдаралаах сабыньньаБын нэлбэгэйдии кэппит, / Үүс тириитэ үллүк са5а / Бэргэһэтин кырыльбалыьы ууруммут / Айыьь киһитэ ааттаақа быһblblлаaх, / Атын илиитигэр сиэтэн баран / Аргыый аБай айгыстан иһэр (Burnashev, 2013: 122).

«From the east / There is a person of unprecedented beauty, / With a beautiful appearance, / With a special purpose, to see, / The best of aiyy people, / an excellent son of the sunny ulus, / Silver reins of a horse / Threw on his right elbow, / Holds in his left hand / A silver cane, / A fur coat with expensive folds/ Made of lynx skin / Put on an open door, / A tall sable hat / Put on leaning to one side slightly, / Leading a horse with the reins/ Walking in an important manner».

The verbs kultey 'to be swollen, inflated; stand out pout, increased in volume in a rounded shape; be convex, bulging' (BEDYL, V. 4: 609 ) and sallay 'thicken to the top or have a thickened front end; to have a disproportionately large head, to be big-headed; to be huge in size, such that the head seems disproportionately large' (BEDYL, V. 8: 198) are used to create an unpleasant appearance of the abaasy (evil) hero: 
Барыта марба киһи быһыbылаах, / Төгүруччү өттө түөс баБадыь киһи, / Тула өттө эргиччи ис быльыblлаах, / Курдатнөнүө куттах быһыbылаах, / Чаан-олгуй са5а саллайбыт бастаах, / Чааскы сађа күлтэйбит харахтардаах киһи эбит' (Burnashev, 2013: 81).

«Naked man of disgusting appearance: Around the body his chest winds, / And the stomach surrounds the entire body, / the stomach is seen through. / The head is like a big tub, / Like big cups, / Are the rotruding bulging eyes».

The verbs horongnoo 'from verb horoy: 1. to be or to seem sticking out; 2. colloquial form of: to become taller, to grow' (BEDYL, V. 13: 602) and tomtoldzhuy 'from verb tomtoy: be or appear to be distinct, rounded, to stand out' (BEDYL, V. 10: 444) are presented in a detailed description of the hero's movements when he is about to speak:

'Итиниэхэ Сылгы уола Дыьырай тыл кэпсии / Өрөөбут уоһун өһүллэ, / Хоммут уоһун хомуйда, / Алтан дьаакыр айабын аппаннатта, / Үрүн көмүс сүөлэгэй күөмэйин көбуөлэттэ. / Уоһа хоронноото, / Уолуга томтолдьуйда, / Үнүү батас курдук / Үтүру-батары көрөн кэбистэ, / Быһaх хатат курдук / Быһa-таһа көрөн кэбистэ' (Burnashev, 2013: 53).

«To this creature ugly as sin/ Dyyray, the strong man, the Son of the Horse / Speaking, / He opened his mouth frozen, / Copper like an anchor, his mouth / Opens, with a silver larynx /He moved and then stuck out his lips, / His throat rises, / Glanced sharply with his eyes, / As if with a sword blade, / As if going to immediately / Cut and shred the enemy into pieces»».

The verb maadzay 'to obtain a bent leg' (BEDYL, V. 6: 176) in the comparison is used in characterizing the actions of the warrior Dyyray during the battle against the abaasy warrior:

'Биһиги киһибит буоллаБына / Икки сотото / Тардыьылаах о5ус буулақатын курдук / Таннары маадьайан түһэн барда, / Иэнин ингирэ киил мас курдук / Кэдэрги тардан барда, / Хатан мас курдук / Ханаччь тардан барда, / Чанчьгын баттақа / Чоноччу тардан барда` (Burnashev, 2013: 57). «Our person's / Two legs the size of two shins, / As the yoke of the ox carrying / The heavy cart is bent, / The veins of the back are shortened, / The body bends upwards, /Like a bent and curved tree, / Hair on the temples / Stand upright».

The verb aybaldzhiy 'smoothly and widely scatter, sway' (Kharitonov, 1954: 285) is used to describe the appearance and body movements of the beautiful Aytaly Kuo:

'Эт бүтэй унуоБа көстөр, / Унуох бүтэй силиитэ дьаккылйар, / Үчүгэй дьахтар, / Көссүө-көссүөтүк көрөн барда, / Нарыннарыннык санара сырытта, / Астаанүөллээн айбалдьвійан барда, / Күөстээнастаан күөгэлдьийэ сырылтта' (Burnashev, 2013: 116).

«Bones turn white through the body, / Through the bones it is clear that she is worried/ The bone marrow - this is how charming she is, / Looking wither tender gaze, / Says something in a quiet voice, / And starts cooking, / Moving so gracefully».

There are several examples in the text of riding a horse with the verb dzhigihiy 'to come into a rocking movement, to shiver, to shutter' (BEDYL, V. 3: 333), for example:

Атын Үрдүк мындаатыгар / Үрүн туллук курдук / Олорон чөмчөөрус гына түстэ, / Соқуруу диэкки барбытын курдук / Баран истэ. / Сиэллэрэн дьигиһитэн истэ, / Хаамтаран хальыһытан истэ, / Уурдаран обустаран истэ' (Burnashev, 2013: 88).

«... and on a horse / As easily as a white bird, / He jumped up, directed as before / To the south. He rides fast with a trot, /Moving quickly, /And galloping».

The verb appangnaa 'from verb appai: 1 . to open slightly, not close completely; 2 . carelessly wide-open mouth' (BEDYL, V. 1: 505), which is used mainly in determining the actions of a person, in this case, is used in the description of the horse's actions:

'Бу сылгы / Үөһэ диэкки өрө көрдө, / Алтан чааньньык айађын аппаннатта, 
/ Урун көмүс Уөлэгэйин көбүөхтэттэ, / Киһи-суөһУ УөскүУ илигинэ, / Айыьы-буруй таарыйа илигинэ, / Сылгы сүөһY тыллаах эбит, / Тыл бө5ө сиикэйдээх, / Олонхотун олонхо омуннаах, / Ити сылгы санараинэрэ турда` (Burnashev, 2013: 84).

«The horse looks up to the sky, / I opened my mouth like / Copper teapot, / I pushed it with a silver larynx. / Before the great breeding / Of the people and cattle, / Until sins took over the world, / Horses could speak / (There is no tale not to lie. / Olonkho makes a wide use of exaggeration. / The horse began to speak».

The actions which are specific to the image of the cow-woman - the Old Woman Simehsin are expressed using the image-forming verbs eppengneie 'barely breathe, breathe' (BEDYL, V. 15: 267), appangnaa 'from verb appai: 1. to open slightly, not close completely; 2. carelessly wide-open mouth' (BEDYL, V. 1: 505) and toytos gyn 'from verb toytoy: 1 . to be or to seem very small and plump (referring to a person's complexion); 2 . to be or to seem very short and stumpy' (BEDYL, V. 10: 424):

'Дьалаана суох санаран барда, / БІпсыbыта суох ыллаан барда, / Этиэн булумуна эппэннии сырытта, / Санарыан булумуна аппанныьы турда... / Унан тиэрэ баран тойтос гына түстэ' (Burnashev, 2013: 101).

«Jumping excitedly, / Speaking in a hurry, screaming, / Barely catching her breath, / She stomped, jumping in one place... She screamed and fainted».

In addition to the example above, many examples are recorded in the description of the home, the hero's weapons and serge. In the description of the outside image of the hero's dwelling, the verb segeldzhit 'slightly lift up, sway' (BEDYL, V. 9: 540) is used to create a heavy, strong-looking door:

Биир өттүгэр биэс уон / Сиэркилэ таас түннүктээх, / Анаар өтттгэр аБыс уон / Айдаан таас түннүктээх, / Соқотох өттугэр тоқус уон / Сөлүудэ таас түннүктээх. / Сиилинэй бухатыьыр тэбинэн сэгэлдьитэн киирэр / Сэттээ уон тиһэх эһэ /
Тириитинэн тигэн дьаптайан оноһуллубут / Лип-хаан хальаннаах эбит' (Burnashev, 2013: 31).

«On one side / Fifty mirrored windows, / On the other half / Noisy glass windows, / On the only side / Ninety mica windows, / And the door is heavy / Sewn in skins / Of seventy large bears, / So firmly made, / That the strongest hero / Can only open it slightly».

In describing the ritual tethering post called serge, the verb bachygyraa 'to be, to seem very close together, forming a row' (BEDYL, V. 2: 280) is used in the part, which explains the location of the tethering posts:

'ТоБус тойон киһи / Утарыта хаамсан киирэн / Дорообо бэрсэн эрэллэрин курдук / Тойон баабыр сэргэтэ / Бачыгырайан көһүннэ' (Burnashev, 2013: 29).

«On the contrary, there are nine / Big tethering posts, / As if nine noble gentlemen / Go towards, greeting / Each other's gracefully».

The verb kylbay '1. to shine brightly; be or seem to be bright or shiny, to glimmer; 2 . to shine with a white light, to whiten, 3. to be or appear to be bright or light-colored; to shine with novelty or freshness' (BEDYL, V. 5: 225) is used in the image-forming description of the spear:

ККытыл унуортан / Кылбайбытынан кэлэр / Kblblc-дьахтар имнээх хааныггар / Хатарыллан оноһуллубут кылааннаах / Хараарар хара дьиэрэнкэй / ҮнүҮлэрдээх эбит' (Burnashev, 2013: 34).

«Spears, hardened / Covered in blood from the face of a young woman, / Playing with black lightning, overtaking the enemy / From the nearby coast, / It turns out he has it».

The verb oloduy 'to look around in all directions, holding his head high; seem energetic, decisive and adventurous' (BEDYL, V. 7: 258) is used in the passage devoted to the fateful sword:

'Унуоргу тыаттан олодуйан кэлэр / Уолан киһи уостаах тииһин хааныгар / Уhааран-кэхтэрэн онорбут / Уорааннаах уһун тайба батастаах эбит' (Burnashev, 2013: 34). 
Blasting from a distant forest / The fatal sword with him / Hardened in blood / From lips and teeth / Young men, dashing / He also has it.

\section{Epic}

2. The Image-Forming Verbs in Tyvan

The image-forming verbs of the Tyvan language are mainly used to describe the characters and their actions. Thus, the verb davy 'bounce with joy' (TRD, 1968: 140) in the extracts found, is used in combination with the verb devi 'to dance' (TRD, 1968: 150); the paired verbs devip-davyp / devigip-davyzhip show masculinity and self-confidence of the main character:

а. 'Узун-Сарыг хаандыва / Хунан-Кара девип-давып, / Маңчнап келген туруп-тур эвеспе аан` (THL, 1997: 232).

«Hunan-Kara and, jumping, [hands ] waving / To [the yurt] of Uzun-Saryg-Khan / He ran up, it turns out»;

b. 'Девижип-давыжып чоруп оргаш, / Дээрниң делгеминге, / Черниң ортузунга / Ужуражып келгештерниң (THL, 1997: 216).

«Jumping, [they] went / Under the expanse of heaven, / On flat ground».

To create a realistic image of an old woman, the image-forming verbs doytuy 'walk, limp' (TRD, 1968: 168) and dyrysh '1. to frown; 2. to scorch' (TRD, 1968: 195) are used:

Куу бутту куду / Куу даян̧гыыш даянып алгаштыц, / Куу даштыг / Кыр тон кедип алгапггың, / Куу шоодай / Чүктеп алгаштың, / Дойтунайнып-дойтунайнып кылаштап, / Кире-ле бергей мен / Хаанның өөндүве / Дырыжаш-дырыжаш, / Чолдашталдаш кире-ле дүже бергей мен' (THL, 1997: 74).

«Dressed in an old-fashioned manner / With a gray top, / With a thrown behind the back / Gray bag, / Leaning on a gray stick / And limping slightly, / I'm down the gray spur descending [going down], / I will come to them [into the aal] / Angry and furious/ Trembling and shaking, / I will enter the Khan's yurt».

The verb kiybyngna 'to fidget, spin; move' (TRD, 1968: 275) is used in combination with the verb imileie 'to swarm' (TRD, 1968: 206) and when describing the horse, this verb emphasizes the horse's playfulness, and a strong desire to be set free:

Хаан кижиниң ара-албатызы / Кара богбаны / Мойнунга уш ораай каккаш, / Өлүг доңнук-биле доңнап-баглап каан, / Адырар дээш, / Чежип чадап каан, / Имилээнкыймыңнаан турар бооп-тур эвеспе аан (THL, 1997: 166).

«The Khan's servants, / To let the iron horse graze, / Clutching and pushing, it turns out, / They tried to untie it / [The reason] why the black shear, / Three times around the neck [iron horse] was wrapped / And tied with a dead knot».

We see the might and strength of the main character in the following example:

'Сарыг кидис хевенектиг / Багай оолдун / Баскан буду / Кыймыш-даа дивес, / Көрген кара / Чивеш-даа дивес...' (THL, 1997: 172).

«And for a poor young man / In a yellow felt hevenek / And walking legs / Did not flinch, / And the looking eyes / Did not blink ...।,

where the verb chivesh-daa means 'to blink; flicker, flicker' (TRD, 1968: 531).

The verb kylchangna 'to look from underneath (viciously)' (TRD, 1968: 276) shows the discontent and anger of the Khan in the passage:

Ђытттавас, кылчануайнып көруп келгештиңу (THL, 1997: 152).

«[The Khan] silently looked from underneath».

The verb saglangayin 'to move, sway, tremble' (TRD, 1968: 360) describes the hero's appearance, conveys all the hero's anxiety and the anxiety for his father, but at the same time the determination and courage of the young hero:

'Улуг өөнге / Бажының конугураазы саглаңайнып, / Балдырының эъди ырбаңһайнып кирип кээрге...' (THL, 1997: 86).

"And he entered the large yurt / With some ruffled hair on his head, / With his leg muscles trembling». 
In one example which was used only once in the text, the verb elengne '1. walk (go) staggering; 2. swing, sway' (TRD, 1968: 612) helps to reveal the image of an old man and an old woman and to understand that they are very old:

'ХҮнүн манап, / ХУУрээн даянган / Ийи ирей, кадай / Элеңейндир кыльшттажы бергештиң, / Хаанның дүжүлгезинге баргаштый (THL, 1997: 110).

«Waiting for their last day to come, / Leaning on a shovel. / And, staggering, they went, / They entered the [yurt with] the Khan's throne».

In another example, the verb elengne is used to depict a picture of a horse-riding:

Хунан-Кара ол чорта бергештиң, / Илби-иидизи-биле / Ийи сыраны тура соккулааштың, / Ийи чеңинге чеңнеп алгаштың, / Элеңњнедип олуруп-тур эвеспе аан' (THL, 1997: 148).

«Then he went, Hunan-Kara / Using sorcery and witchcraft / He pulled out two poles, / He hid himself in the sleeves / And he rode his horse, swaying, it turns out».

In the text, the verb elengne is indicated in combination with the verb tendingeier 'stagger, swing (in case of loss of balance)' (TRD, 1968: 410). Basically, they convey the picture of a hero riding his horse:

Арзылаң-Кара-даа / Өлүр чеде берген / Өктек кара богба бооп / Дүжүп турган иргин ийин, / Моң ьяяш эзеңฺгилиг, / Морзук кежи төрепчилиг, / Kbызытпа чальг, / Кыпсынчыг-чаржынчыг амытан бооп алгаш, / Элеңнедип-тендиңңедип, / Чоруп олуруп-тур эвеспе аан` (THL, 1997: 142).

«Arzylan-Kara / Turned / Into a lousy black shear, / Who is about to die. / Having become miserable, insignificant, / [Hunan-Kara] rode / With a small bow, / Swinging-swaying / In stirrups made of wood / On a badger made of badger skin».

In paired use with the verb khalangna 'hang out (about smth.)' (TRD, 1968: 464), the verb elengne also represents riding a horse:

'Халаңнады-элеңнеди / Көруп чортупдаа олурган иргин ийин' (THL, 1997: 260).
«Swinging, swaying, / Riding, watching [Hunan-Kara] makes his way».

There is an example of $a$ dwelling description: the verb herelden 'to radiate, to give off light, emit rays; to spread (rays)' (TRD, 1968: 276 ) is found in the image of the Khan's house, it emphasizes the beauty and grandeur of the house:

Даң бажы шара-хере, / Даш бажы кара-иокар хиреде, / Кода-хурээ ортузунда / Херелденип турар алдын бажың / Косту берген туруп-тур` (THL, 1997: 156).

«When the dawn came/ And the tops of the mountains became crimson-warm, / In the middle of the palace headquarters / the Golden House / Shining appeared».

The last example refers to the description of a natural phenomenon: the verb chyrytkylash de- 'shine, glimmer, flicker' (TRD, 1968: 559 ) is used to show the speed of time and action - for a moment it becomes light and the interlocutors disappear:

Депкен дег болза, / Демир аъдын мунган дег болза, / Ямбы-дип чырыткылаш / Дээн дег болза, / Дээрдиве үнгени-даа көзүлбес, / Чердиве киргени-даа көзүлбес, / Бар чыткан барааны-даа чок, / Ямбы-дип кара чаңгыс / Чырыткылаш дээн дег болза, / Барган угшии көзулбейн / Барган туруп-тур эвеспе аан' (THL, 1997: 134).

«He said / And his legs [in stirrups] seemed to be wedged, / I would have sat down on an iron horse, / Yamby-dip seems to be / Lit up for a moment, / But even the appearance of the departing one did not flicker: / It could not be clearly visible whether it ascended into the sky, / It was not visible whether it went underground. / Only for a brief moment / Yamby-dip was illuminated: / He left - and it was nowhere to be seen, it turns out / In which direction [he] went».

It should be added that some verbs, depending on the context, can be used to perform different functions. In the Yakut language, from the verbs found in olonkho, 5 verbs perform several functions: the verb aybaldzhiy is used to describe nature and the 
actions of a character; the verb kylbay is used to describe the weapons of a hero, nature and a character; the verb chikkey participates in the description of the hero's weapon, the character's actions and the character himself. In the Tyvan language, the verb elengne, as had been mentioned earlier, is used many times and is found in descriptions of the character's actions and in the description of horse-riding.

\section{Conclusion}

Thus, we have made a classification of image-forming verbs of the Yakut and Tyvan languages based on the work of L. Kharitonov. Among the indicated verbs in the Yakut language, the verbs of the visual image exceed in number; namely the verbs characterizing the appearance, form and structure of the object; in the Tyvan language, verbs of movement characterizing the manner of walking, movement of the body and parts of the body predominate. This gives us the opportunity to conclude that the Yakut olonkho teller pays more attention to a detailed and figurative description for creating an entertaining plot, colorful images and actions; while the Tyvan epic tale storyteller focuses on movements, the course of actions for creating a lively and bright course of events, and developing the plots. The structure of the image-forming verb stems is analyzed and it is noted that the Yakut verbs are used in their original forms and in the forms created using affixes of specific forms. Tyvan verbs are used in forms based on the use of affixes of word formation derived from verbs and auxiliary verbs. In addition, the Tyvan image-forming verbs both of double and paired use are common. According to the stem structure and the word semantics, only one equivalent was found among the image-forming verbs found in the course of analysis. As a result of the analysis of the functional features of the Yakut and Tyvan image-forming verbs in epic texts, we can note that their peculiarity and general features are manifested in their direct participation in creating images, describing the scenery, characterizing actions and transmitting feelings.

\section{References}

Argunova, K.V., Sorova, I.N. (2019). Fonostrukturnaia i intonatsionnaia realizatsiia glagolov zritel'nogo obraza $\mathrm{v}$ iakutskom i kirgizskom iazykakh [Phonostructural and intonation realization of visual image-forming verbs in the Yakut and Kyrgyz languages]. In Kategoriia obraznosti v iazyke (na materiale sopostavleniia iakutskogo iazyka s kazakhskim, kirgizskim, altaiskim i mongol'skim iazykami): kollektivnaia monografiia [Category of imagery in language (based on the comparison of the Yakut language with the Kazakh, Kyrgyz, Altai and Mongolian languages): a collective monograph], 43-68.

Baskakov, N.A. (1969). Vvedenie v izuchenie tiurkskikh iazykov [Introduction to the study of Turkic languages]. Moscow, Vysshaia shkola, $383 \mathrm{p}$.

BEDYL - Sleptsov, P.A. (Ed.) (2004-2015). Bol'shoi tolkovyi slovar' iakutskogo iazyka [Big explanatory dictionary of the Yakut language]: in 15 volumes. Novosibirsk, Nauka.

Burnashev, I.I. - Tong Suorun (2013). Syn loshadi Bogatyr' Dyyrai: olonkho [Dyyray Bogatyr, The Son of the Horse: olonkho]. Yakutsk, Izdatel'skii dom SVFU, 376 p.

Dorzhu, Ch.M. (1980). O foneticheskikh i strukturnykh osobennostiakh podrazhatel'nykh slov tuvinskogo iazyka [About phonetic and structural features of imitative words of the Tuvan language]. In Tuvinskaia pis'mennost', iazyk i literatura [Tuvan writing, language and literature], 80-91.

Efremov, N.N. (2017). Obraznye glagoly, formiruiushchie prostranstvennye predlozheniia, v iakutskom iazyke (strukturno-semanticheskii analiz) [Image-forming verbs that form spatial sentences in the Yakut language (structural and semantic analysis)]. In Severo-Vostochnyi gumanitarnyi vestnik [North-Eastern humanitarian bulletin], 3 (20), 112-118.

Gogoleva, M.T. (2015). K probleme geneticheskikh sviazei olonkho i tuvinskikh geroicheskikh skazanii [On the problem of genetic links between olonkho and Tyvan heroic legends]. In Filologiia i chelovek [Philology and people], 3, 78-87. 
Hertek, L.K. (2015). K voprosu o lingvisticheskom analize epicheskikh tekstov [On the question of linguistic analysis of epic texts]. In Filologicheskie nauki. Voprosy teorii i praktiki [Philological sciences. Questions of theory and practice], 12 (54), Part I., 188-190.

Iskhakov, F.G., Pal'mbakh, A.A. (1961). Grammatika tuvinskogo iazyka. Fonetika i morfologiia [Grammar of the Tyvan language. Phonetics and morphology]. Moscow, Izdatel'stvo vostochnoi literatury, 472p.

Kharitonov, L.N. (1947). Sovremennyi iakutskii iazyk. Fonetika i morfologiia [Modern Yakut language. Phonetics and morphology]. Yakutsk, Gosizdat IaASSR, 320 p.

Kharitonov L.N. (1954). Tipy glagol'noi osnovy v iakutskom iazyke [Types of the verbal stems in the Yakut language]. Moscow; Leningrad, Izdatel'stvo Akademii nauk SSSR, 312 p.

Kharitonov L.N. (1960). Formy glagol'nogo vida v iakutskom iazyke [Verb forms in the Yakut language]. Moscow; Leningrad, Izdatel'stvo Akademii nauk SSSR, 179 p.

Koryakina, A.F. (2020). Analogii v iakutskom olonkho i tuvinskom epose: siuzhetno-kompozitsionnyi stroi, motivy (na materiale eposov «Niurgun Bootur Stremitel'nyi» G.K. Orosina i «Khunan Kara» Chanchy-Khoo Oorzhak) [Analogies in the Yakut olonkho and Tyvan epic: plot-compositional structure, motives (based on the epics "Nyurgun Bootur the Swift" by G.K. Orosin and "Khunan Khara" by Chanchy-Hoo Oorzhak)]. In Nauchnyi dialog [Scientific dialogue], 5, 303-319. DOI: 10.24224/22271295-2020-5-303-319

Monastyrev, V.D. (2019). Leksicheskie sredstva vyrazheniia kategorii obraznosti v iakutskom i mongol'skom iazykakh (na materiale obraznykh glagolov vizual'nogo deistviia, kharakterizuiushchikh dvizhenie) [Lexical means of expressing the category of figurativeness in the Yakut and Mongolian languages (based on image-forming verbs of visual action that characterize movement)]. In Kategoriia obraznostiv iazyke (na materiale sopostavleniia iakutskogo iazyka s kazakhskim, kirgizskim, altaiskim i mongol'skim iazykami): kollektivnaia monografiia [Category of imagery in language (based on the comparison of the Yakut language with the Kazakh, Kyrgyz, Altai and Mongolian languages): a collective monograph], 163-175.

Oboiukova, V.V. (2015). Comparative analysis of epic subjects (based on the Yakut and Tyvan epics) [Sravnitel'nyi analiz epicheskikh siuzhetov (na materiale iakutskogo i tuvinskogo eposov)]. In Materialy Vserossiiskoi nauchnoi konferentsii, posviashchennoi 110-letiiu I.V. Pukhova, "Sravnitel'noe izuchenie tiurko-mongol'skikh eposov" [Materials of the All-Russian scientific conference dedicated to the 110th anniversary of I.V. Pukhov "Comparative study of the Turkic-Mongolian epics"]. Yakutsk, 59-68.

Ondar, N.M. (2004). Parnye slova v tuvinskom iazyke [Paired words in the Tyvan language]. Dissertation Abstract. Moscow, Institut iazykoznaniia RAN, 21p.

Pukhov, I.V. (2003). Geroicheskii epos tiurko-mongol'skikh narodov Sibiri. Obshchnost', skhodstva, razlichiia [The heroic epic of the Turkic-Mongol peoples of Siberia. Commonality, similarities, differences]. Available at: http://www.elibrary.az/docs/jurnal/jrn2015_462.pdf

Putilov, B.N. (1978). Problemy epicheskogo tvorchestva narodov Sibiri i Dal'nego Vostoka v svete sovremennogo eposovedeniia [Problems of epic creativity of the peoples of Siberia and the Far East in the light of modern epic studies]. In Materialy Vsesoiuznoi konferentsii fol'kloristov "Epicheskoe tvorchestvo, narodov Sibiri i Dal'nego Vostoka" [Materials of All-unions conference of folklorists "Epic creativity of the peoples of Siberia and the Far East"'], Yakutsk, 8.

Rassadin, V.I. (1981). Problemy obshchnosti v tiurkskikh iazykakh Saiano-Altaiskogo regiona [Community problems in the Turkic languages of the Sayano-Altai region]. In Tiurkologicheskii sbornik [Turkological collection], 219-231.

Sereedar, N.Ch. (2011). Semanticheskie varianty modeli zvuchaniia prostykh predlozhenii v tuvinskom iazyke [Semantic variants of the sound model of simple sentences in the Tuvan language]. In Vestnik Universiteta Rossiiskoi akademii obrazovaniia. Filologiia i zhurnalistika [Bulletin of the University of the Russian Academy of Education. Philology and journalism], 2, 43-46.

Shamaeva, A.E., Prokop'eva, S.M. (2019). Obraznye glagoly iakutskogo iazyka, kharakterizuiushchie chasti tela cheloveka v sopostavlenii s mongol'skim iazykom [Image-forming verbs of the Yakut language, characterizing parts of the human body in comparison with the Mongolian language]. In Kategoriia obraznosti v iazyke (na materiale sopostavleniia iakutskogo iazyka s kazakhskim, kirgizskim, altaiskim i mon- 
gol'skim iazykami): kollektivnaia monografia [Category of imagery in language (based on the comparison of the Yakut language with the Kazakh, Kyrgyz, Altai and Mongolian languages): a collective monograph], 147-163.

THL - Orus-ool, C.M. (Ed.) (1997). Tuvinskie geroicheskie skazaniia [Tyvan heroic legends]. Novosibirsk, Nauka, 584 p. - (Monuments of folklore of the peoples of Siberia and the Far East; V. 12).

TRD - Tenishev, E.R. (Ed.) (1968). Tuvinsko-russkii-russkii slovar' [Tuvan-Russian Dictionary]. Moscow, Sovestkaia entsiklopediia, $648 \mathrm{p}$.

Ubriatova, E.I. (1960). Iakutskii iazyk v ego otnoshenii k tiurkskim, mongol'skim, a takzhe tunguso-man'chzhurskim iazykam [The Yakut language in its relation to the Turkic, Mongolian, and also the Tungus-Manchu languages]. Moscow, $34 \mathrm{p}$.

Zhirkova, E.E. (2017). Osobennosti obraznykh glagolov, vyrazhaiushchikh pokhodku cheloveka, v iakutskom iazyke (s privlecheniem materiala iaponskogo iazyka) [Features of image-forming verbs expressing a person's gait in the Yakut language (using the material of the Japanese language)]. In Severo-Vostochnyi gumanitarnyi vestnik [North-Eastern humanitarian bulletin], 3 (20), 118-124. 